\title{
The Effectiveness of Application of Moodle Software in Traditional Sports Game Courses
}

\author{
Zihan Novita Sari $^{1, *}$, Arief Darmawan ${ }^{1}$, Surya Adi Saputra ${ }^{1}$, Qorry Armen Gemael ${ }^{2}$, Oktariyana $^{3}$ \\ ${ }^{1}$ Department of Physical Health and Recreation Education, State University of Malang, East Java, Indonesia \\ ${ }^{2}$ Department of Sports Science, Singaperbangsa Karawang University, West Java, Indonesia \\ ${ }^{3}$ Department of Physical Education, PGRI Palembang University, South Sumatera, Indonesia
}

Received July 29, 2021; Revised October 15, 2021; Accepted November 11, 2021

\section{Cite This Paper in the following Citation Styles}

(a): [1] Zihan Novita Sari, Arief Darmawan, Surya Adi Saputra, Qorry Armen Gemael, Oktariyana, "The Effectiveness of Application of Moodle Software in Traditional Sports Game Courses," International Journal of Human Movement and Sports Sciences, Vol. 9, No. 6, pp. 1383 - 1389, 2021. DOI: 10.13189/saj.2021.090634.

(b): Zihan Novita Sari, Arief Darmawan, Surya Adi Saputra, Qorry Armen Gemael, Oktariyana (2021). The Effectiveness of Application of Moodle Software in Traditional Sports Game Courses. International Journal of Human Movement and Sports Sciences, 9(6), 1383 - 1389. DOI: 10.13189/saj.2021.090634.

Copyright $\odot 2021$ by authors, all rights reserved. Authors agree that this article remains permanently open access under the terms of the Creative Commons Attribution License 4.0 International License

\begin{abstract}
This research aims to determine the effectiveness of Moodle software to improve student learning outcomes in traditional sports game courses. This research uses a quantitative approach. The design used in this study is the pretest-posttest control group design. This research uses a student cognitive test instrument to measure the increase in student learning outcomes in traditional sports game courses. Based on the results of the test of information on the ability test of student learning outcomes with the test subject again 40 students ( 20 students for the experimental class and 20 students for the control class) obtained a significance value (sig.) in both the Kolmogorov-Smirnov test or the Shapiro-test. Wilk 0.05 so that the data are normally distributed. Then, the test was carried out using an independent sample test, the value of Sig. (2-tailed) was $0,000 \& l t ; 0.05$ so that Ho (Statistical Hypothesis) is rejected and Ha (Alternative Hypothesis) is accepted so that there is a significant average difference between the post-test results of the experimental group and the post-test of the control group. Based on the N-Gain score test, the average $\mathrm{N}$-gain score for the experimental class was 0.7 , the findings were 0.85 in the high category. Meanwhile, the average $\mathrm{N}$-gain score for the control class is 0.3 , which is 0.34 with a low type. So it can be concluded that the implementation of Moodle software can improve student learning outcomes in traditional sports game courses.
\end{abstract}

Keywords Application, Moodle Software, Traditional
Sports Games

\section{Introduction}

Traditional sports games are a new course at the Faculty of Sports Science at the Health and Recreation Physical Education Study Program, State University of Malang. In the curriculum for physical education, health, and recreation, traditional sports game courses are included in the category of elective courses. This course discusses the basic concepts and types of traditional sports games, and the moral values that exist in the game, as well as how to play the game and know the types of games and the development of traditional sports as a form of physical activity.

Traditional games are games that are no less exciting than modern games, because traditional games can train imagination, thinking, and unconsciously movements that require good energy or fitness and good basic movement activities [1]. Herlambang [2] explains that "traditional games are the result of extracting from their own culture which contains many educational values because the game activities provide a sense of pleasure, joy, and cheerfulness to the children who play them. In addition, the games are played in groups to create a sense of democracy between playmates and the game tools used 
are relatively simple".

While traditional sports are the original games of the people as a national cultural asset that has elements of traditional physical exercise [3]. According to Harwandi [4] "traditional sports are community games that have limitations in society, grow and develop orally which are passed down from generation to generation". Furthermore, Hasbi \& Sukoco [5] stated that traditional sports must meet two requirements, namely in the form of "sports" and at the same time "traditional", both in having a tradition that has developed for several generations or in the sense of something related to the cultural traditions of a nation more broadly. Gazali et al., [6] said that "Traditional sports or traditional games in various regions have their characteristics and privileges and reflect the noble values of culture". Traditional sports are sports that developed from folk games that arise in every ethnic and ethnic group in Indonesia [7]. Harismi [8] explains that "traditional sports are all sports activities that have been recognized as a hereditary tradition in a certain tribe, ethnicity, or cultural group in Indonesia. Traditional sports usually rely on the strength, flexibility, speed, and accuracy of the reactions of the players.

Learning in this pandemic period, especially in learning traditional sports game courses, $80 \%$ of face-to-face practices are expected into remote learning where all teaching and learning activities are carried out online, this is the biggest challenge for all educators to be able to apply online learning media appropriate and effective for students who in this context are students so that the objectives of learning can be achieved optimally. The use of online learning applications is widely used at various levels of education. Thus, many have developed online-based learning platforms to support the needs in the field of education.

Moodle is a platform that can be used by users in creating and developing electronic-based learning devices (e-learning). Melfachrozi [9] explains that "Moodle is a software package produced for internet and website-based learning activities". Modular Object-Oriented Dynamic Learning Environment or an abbreviation of Moodle is a platform used to support online learning management systems and using computers [10]. Moodle is a world-famous education management system [11]. Moodle is also a web-based application. Which, for each learning activity related to material access, discussion, question, and answer, to evaluation can be done through the website display using the help of a browser. So, in carrying out learning of traditional sports game courses that are carried out online, what is considered appropriate is to use learning applications such as e-learning Moodle as the best choice. This platform is open source and can be used for free. Through this Moodle application, learning becomes flexible and creates a comfortable atmosphere during the teaching and learning process, learning using Moodle media can cause a positive response for students because there is a lot of material provided in the form of interesting videos so that students not only see and listen but want to. Moving even with a remote learning system, and also very helpful for lecturers in preparing any material that will be presented to students in a procedure according to the Lesson Plan for traditional sports game courses. Thus, it can be a solution for teaching and learning that is cheap but still effective. In addition, this platform is mobile-friendly. This will certainly make it easier to access learning materials anytime, anywhere. Oktariyana et al., [12] said that "It is the answer to the problems that occurred during the COVID-19 pandemic which demanded that learning be carried out online or virtual which is often referred to as distance learning".

With the implementation of Moodle software as a learning medium in traditional sports game courses during the COVID-19 pandemic, it is hoped that it can be useful and become one of the appropriate and effective learning media in increasing student interaction with fellow students and with lecturers as teachers - Unlimited learning resources. In addition, it is expected to improve the quality of learning activities between lecturers and students, because information can be explored as widely as possible and there are no limits. It is also hoped that the application of Moodle software in traditional sports game courses can improve student learning outcomes for traditional sports game courses.

\section{Research Methods}

This research uses a quantitative approach with the design used in this research is a pretest-posttest control group design [13]. This research has been carried out in the Department of Physical Education, Health and Recreation, State University of Malang face-to-face. The effectiveness test with the test subjects totaled 40 students (20 students for the experimental class (using Moodle software) and 20 students for the control class (conventional education)). The instrument for collecting information in this research is to use a student cognitive test instrument to identify the improvement in student learning outcomes in traditional sports game courses before and after being given treatment. The data analysis method used in this research is quantitative. The data were analyzed using a t-test to determine whether there was a significant effect on the implementation of the Moodle application, namely the independent samples t-test.

The test instrument given is in the form of 20 questions in the form of multiple options to determine the improvement in student learning outcomes before and after the application of the Moodle application for traditional sports game courses. Next, to determine the effectiveness of the implementation of the Moodle application, it was analyzed using the N-Gain Score test. Sundayana [14] explains that "N-gain (Normalized Gain) 
is used to measure the increase in science process abilities and cognitive learning outcomes between before and after learning". The following is the formula for the N-Gain Score test:

$$
N \text { Gain }=\frac{\text { Skor Posttest }- \text { Skor Pretest }}{\text { Skor Ideal }- \text { Skor Pretest }}
$$

Source: Hake in Sundayana [15]

Figure 1. N-Gain Score Formula

Meanwhile, for the categorization of the $\mathrm{N}$-gain score, it can be determined based on the $\mathrm{N}$-gain value. There are also types of $\mathrm{N}$-gain value acquisition, which can be seen in Table 1:
Table 1. Category Score Gain

\begin{tabular}{|c|c|}
\hline N-Gain Value & Category \\
\hline $\mathrm{g}>0,7$ & Tall \\
\hline $0,3 \leq \mathrm{g} \leq 0,7$ & Currently \\
\hline $\mathrm{g}<0,3$ & Low \\
\hline
\end{tabular}

Source: Meltzer [16]

\section{Results and Discussion}

In this effectiveness test using subjects as many as $\mathrm{N}=$ 40 students, the information obtained from students' cognitive test results (the ability to study results in Traditional Sports Games courses) can be seen in Table 2 below:

Table 2. Student Cognitive Test Results Data

\begin{tabular}{|c|c|c|c|c|}
\hline \multirow{3}{*}{ Trial Subject } & \multicolumn{4}{|c|}{ Group } \\
\hline & \multicolumn{2}{|c|}{ Experiment } & \multicolumn{2}{|c|}{ Control } \\
\hline & Pretest & Posttest & Pretest & Posttest \\
\hline 1 & 62 & 75 & 60 & 72 \\
\hline 2 & 60 & 80 & 71 & 73 \\
\hline 3 & 64 & 85 & 65 & 74 \\
\hline 4 & 62 & 83 & 76 & 77 \\
\hline 5 & 62 & 86 & 77 & 79 \\
\hline 6 & 61 & 80 & 55 & 77 \\
\hline 7 & 71 & 88 & 73 & 75 \\
\hline 8 & 71 & 80 & 74 & 76 \\
\hline 9 & 70 & 81 & 60 & 75 \\
\hline 10 & 68 & 82 & 72 & 73 \\
\hline 11 & 75 & 84 & 78 & 78 \\
\hline 12 & 71 & 83 & 74 & 74 \\
\hline 13 & 75 & 82 & 77 & 77 \\
\hline 14 & 73 & 84 & 76 & 78 \\
\hline 15 & 73 & 85 & 64 & 75 \\
\hline 16 & 71 & 80 & 74 & 75 \\
\hline 17 & 65 & 81 & 64 & 73 \\
\hline 18 & 64 & 84 & 70 & 71 \\
\hline 19 & 62 & 88 & 72 & 73 \\
\hline 20 & 65 & 80 & 63 & 76 \\
\hline
\end{tabular}


From the data from the test results, a normality test was then carried out, with the results obtained as shown in table 3 below:

Table 3. Data Normality Test

\begin{tabular}{ccccccccc}
\hline & \multirow{2}{*}{ Class } & \multicolumn{2}{c}{ Kolmogorov-Smirnov $^{\text {a }}$} & \multicolumn{3}{c}{ Shapiro-Wilk } \\
\cline { 3 - 8 } & & Statistic & df & Sig. & Statistic & df & Sig. \\
\hline & Pretest Experiment & .172 & 20 & .122 & .902 & 20 & .245 \\
\cline { 2 - 8 } & PostTest Experiment & .157 & 20 & $.200^{*}$ & .950 & 20 & .367 \\
$\begin{array}{c}\text { Student Learning Outcomes of } \\
\text { Traditional Sports Game } \\
\text { Course }\end{array}$ & Pretest Control & .180 & 20 & .132 & .905 & 20 & .101 \\
& Posttest Control & .126 & 20 & $.200^{*}$ & .968 & 20 & .714 \\
\hline
\end{tabular}

a. Lilliefors Significance Correction

*. This is a lower bound of the true significance.

Based on the data test results table above, it is known that the significance value (sig.) in both the Kolmogorov-Smirnov test and the Shapiro-Wilk test is $>0.05$, so it can be said that the research data has a normal distribution, then a t-test was performed using the independent samples test. The following are the results of the t-test scores for the experimental group and the control group posttest as shown in table 4 below:

Table 4. The Average Value of the Test Results

\begin{tabular}{cccccc}
\hline & Class & N & Mean & Std. Deviation & Std. Error Mean \\
\hline Student Learning Outcomes of & Postest Experiment & 20 & 82.55 & 3.120 & .698 \\
\cline { 2 - 6 } Traditional Sports Game Course & PostTest Control & 20 & 75.05 & 2.188 & .489 \\
\hline
\end{tabular}

Based on the output results in the group statistics above, it can be seen that the average learning ability test results of students in the traditional sports game subject in the experimental class are $=82.55$ and the standard deviation is $=$ 3.120 , while the average test results for students in the traditional sports game in the control class are $=75.05$ with a standard deviation of $=2.188$. So it can be said that student learning outcomes in the experimental class traditional sports game course are better than student learning outcomes in the control class traditional sports game course.

Table 5. T-Test Results

\begin{tabular}{|c|c|c|c|c|c|c|c|c|c|c|}
\hline & & \multicolumn{2}{|c|}{$\begin{array}{c}\text { Levene's Test for } \\
\text { Equality of Variances }\end{array}$} & \multicolumn{7}{|c|}{ t-test for Equality of Means } \\
\hline & & \multirow[b]{2}{*}{$\mathrm{F}$} & \multirow[b]{2}{*}{ Sig. } & \multirow[b]{2}{*}{$\mathrm{t}$} & \multirow[b]{2}{*}{ df } & \multirow{2}{*}{$\begin{array}{c}\text { Sig. } \\
\text { (2-tailed) }\end{array}$} & \multirow{2}{*}{$\begin{array}{c}\text { Mean } \\
\text { Difference }\end{array}$} & \multirow{2}{*}{$\begin{array}{l}\text { Std. Error } \\
\text { Difference }\end{array}$} & \multicolumn{2}{|c|}{$\begin{array}{l}95 \% \text { Confidence } \\
\text { Interval of the } \\
\text { Difference }\end{array}$} \\
\hline & & & & & & & & & Lower & Upper \\
\hline \multirow{2}{*}{$\begin{array}{l}\text { Student Learning } \\
\text { Outcomes of } \\
\text { Traditional Sports } \\
\text { Game Course }\end{array}$} & $\begin{array}{l}\text { Equal variances } \\
\text { assumed }\end{array}$ & 1.927 & .173 & 8.802 & 38 & .000 & 7.500 & .852 & 5.775 & 9.225 \\
\hline & $\begin{array}{l}\text { Equal variances not } \\
\text { assumed }\end{array}$ & & & 8.802 & 34.048 & .000 & 7.500 & .852 & 5.768 & 9.232 \\
\hline
\end{tabular}

Based on the results of the output above, is known the value of sig. (2-tailed) which is $0.000<0.05$, then Ho (statistical hypothesis) is rejected and $\mathrm{Ha}$ (alternative hypothesis) is accepted so that there is a significant average difference between the post-test results of the experimental group and the post-test control group. Thus there is a significant increase in student learning outcomes in traditional sports game courses after the application of Moodle software. Furthermore, to determine the effectiveness of the application of Moodle software, it can be tested by calculating the N-Gain Score. 
Table 6. Descriptives

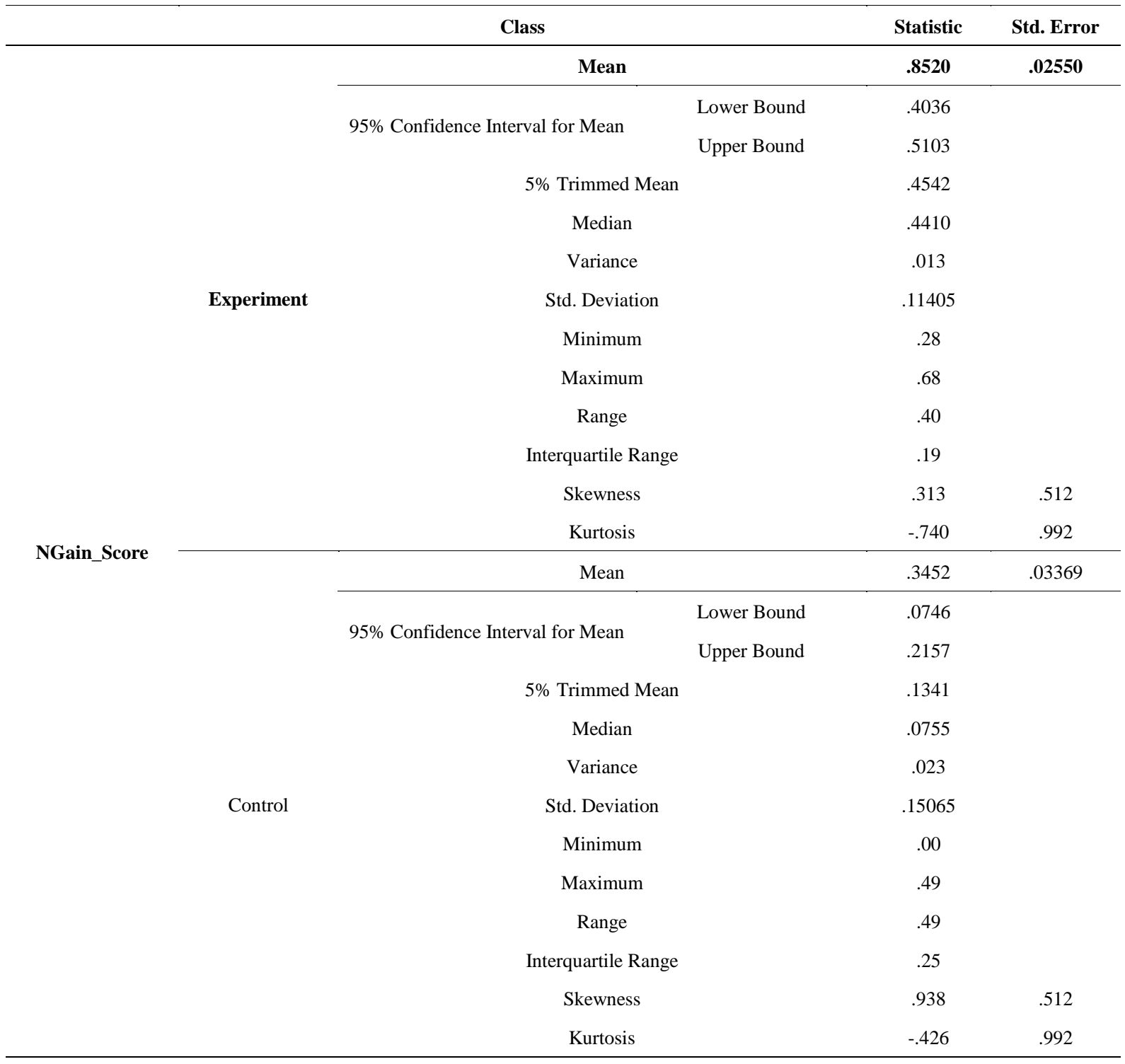

Based on the results of the n-Gain score in the table above, it is known that the average n-Gain Score for the experimental class is $>0.7$ which refers to table 1 (the distribution of Gain scores) which is 0.8 in the high category. Meanwhile, the average $\mathrm{N}$-gain score for the control class is $<0.7$ which refers to table 1 (the distribution of the Gain score) which is 0.3 in the low category. Thus, the effective application of Moodle software can improve student learning outcomes in traditional sports game courses.

The results of this study are in line with research from Nasol [17] which explains that learning with the application of web-based learning media through the Moodle portal has proven to be interesting and effective in improving learning outcomes. In addition, based on the results of a study from Turrahma et al., [18] said the use of e-learning can improve the quality of teachers. Teachers can improve their abilities and explore new knowledge and can be taught to students using information and communication technology approaches. Learning activities are achieved by the design of teaching and learning activities without any limitations of space and time. And research from Yuliana \& Fitri [19] reveals that Moodle as a complement to the blended learning system in learning is feasible and effective to use in the learning process.

\section{Conclusions}

The conventional method is still considered better by students than using the method with the application of Moodle software because it is easier to understand the material and also easier to interact with the teacher. However, the method using the Moodle software itself is much better than the conventional method, especially during the Covid-19 pandemic, which is proven based on the results of research that has been done that the 
application of Moodle software in traditional sports game courses has been proven to be effective in improving student learning outcomes, which obtained from the results of testing the independent sample test data, namely the value of sig. (2-tailed) $<0.05$ so that there is a significant increase before and after the application of Moodle software in traditional sports game courses, and based on the results of the n-Gain score test, the results of $\mathrm{n}$-Gain $>0.7$ refer to table 1 (Gain score distribution) that is equal to 0.75 with high category.

The advantages of the Moodle software are; 1) Complete features: Moodle software provides complete features for a learning process, including features for communication (chat, messaging, or forums), features for the creation and administration of learning materials, features for tracking and following the progress of the learning process, features for feature expansion flexible. 2) Ease of use, because almost all components in Moodle Software can be externally and flexibly arranged according to the policies and needs of the learning process. Besides having the advantages of Moodle software, it also has disadvantages including; 1) Does not always support existing web browsers, although it can be updated by downloading the latest Moodle application. 2) In the choice of language there are still some parts in the e-Learning display that cannot be changed.

The research follow-up plan is that researchers will disseminate the results of this research to universities in Indonesia so that they can be used as references for learning media that can be used in the learning process, especially in traditional sports game courses during the Covid-19 pandemic. Furthermore, the author will continue research with different themes and materials as well as with an even better online learning media base.

\section{Acknowledgments}

The authors would like to thank the Faculty of Sport Science, Physical Education, Health and Recreation, the State University of Malang for supporting researchers in carrying out this research.

\section{REFERENCES}

[1] Elisyah, V., Tangkudung, J., Puspitorini, W., Oktariyana, Sovensi, E., Mudian, D., Setiawan, H., \& Lanos, M. E. C. (2021). Basic Athletic Motion of 40 Meters Running Based on the Traditional Lahat Game at the Elementary School Level. International Journal of Human Movement and Sports Sciences, 9(3), 522-528. https://doi.org/10.13189/sa j.2021.090318

[2] Herlambang, T. (2017). Olahraga Tradisional Sebagai Identitas Budaya Indonesia. Strategi Kebudayaan Dan Tantangan Ketahanan Nasional Kontemporer.

[3] Herlambang, T. (2017). Olahraga Tradisional Sebagai
Identitas Budaya Indonesia. Strategi Kebudayaan Dan Tantangan Ketahanan Nasional Kontemporer.

[4] Herwandi, Sugiyanto, \& Doewes, M. (2017). Paraga Game As Traditional Sports For Bugis Makassar Tribal Communities In South Sulawesi, Indonesia. European Journal of Physical Education and Sport Science, 3(3), 1326.

[5] Hasbi, \& Sukoco, P. (2014). Pengembangan Model Pembelajaran Motorik Dengan Modifikasi Permainan Tradisional Untuk Sekolah Dasar Kelas Atas. Jurnal Keolahragaan, 2(1), 46-58.

[6] Gazali, N., Cendra, R., \& Putra, Y. (2018). Perkembangan Olahraga Tradisional Pacu Jalur Di kabupaten Kuantan Singingi Provinsi Riau. Jurnal SPORTIF : Jurnal Penelitian Pembelajaran, 4(2). https://ojs.unpkediri.ac.id/index.php/pj $\mathrm{k} /$ article/view/12324/1019

[7] Khamdani, A. (2010). Olahraga Tradisional Indonesia. PT. Mancanan Jaya Cemerlang.

[8] Harismi, A. (2021). Berbagai Olahraga Tradisional Indonesia dan Permainan yang Seru. Www.Sehatq.Com. https://www.sehatq.com/artikel/olahraga-tradisional-indon esia-yang-seru-untuk-dimainkan

[9] Melfachrozi. (2013). Penggunaan Aplikasi e-Learning (Moodle). IlmuKomputer.Com.

[10] Adani, M. R. (2021). Panduan Lengkap Menggunakan Moodle untuk Pemula. Www.Sekawanmedia.Co.Id. https://www.sekawanmedia.co.id/pengertian-moodle/

[11] Moodle. (2021). Memulainya itu Mudah. Https://Moodle.Org/.

[12] Oktariyana, Asmawi, M., Sulaiman, I., Oktariyani, Sukmawati, N., Lanos, M. E. C., \& Lestari, H. (2021). Design of Mobile Learning Rhythmic Gymnastics Materials for High School / Vocational High School Levels as a Distance Learning Media during the Covid-19 Pandemic. International Journal of Human Movement and Sports Sciences, 9(3), 394-402. https://doi.org/10.13189/saj .2021 .090302

[13] Sugiyono. (2015). Metode Peneliltian Pendidikan Pendekatan Kuantitatif, Kualitatif, dan R\&D. Alfabeta.

[14] Sundayana, Rostina. (2014). Statistika Penelitian Pendidikan. Bandung: Alfabeta.

[15] Sundayana, R. 2016. Statistika Penelitian Pendidikan. Bandung: Alfabeta.

[16] Meltzer, D. E. 2002. "The Relationship Between Mathematics Preparation and Conceptual Learning Grains in Physics: A Possible 'Hidden Variable' in Diagnistice Pretest Score." American Journal Physics 70(12).

[17] Nasol, M. F. (2017). Pengembangan Media Pembelajaran Tematik Integratif Berbasis Website Melalui Portal Moodle pada Kelas 5 Madrasah Ibtidiyah Negeri 2 Malang. Universitas Islam Negeri Maulana Malik Ibrahim Malang.

[18] Turrahma, A., Satyariza, E. N., \& Ibrahim, A. (2017). Pemanfaatan e-Learning Berbasis LCMS Moodle dalam Peningkatan efisiensi dan efektivitas serta kualitas Media Pembelajaran Siswa di MAN Sakatiga. JANAPATI: Jurnal Nasional Pendidikan Teknik Informatika, 6(3), 327-332. 
https://doi.org/10.23887/janapati.v6i3.12672

[19] Yuliana, I., \& Fitri, L. Z. (2019). Efektivitas Penerapan Blended Learning dengan Moodle sebagai Media
Pembelajaran untuk Mata Pelajaran Simulasi Digital. PROtek: Jurnal Ilmiah Teknik Elektro, 6(1). https://doi.org/10.33387/protk.v6i1.998 